\title{
繊維強化型 $\mathrm{Nb}_{3} \mathrm{Sn}$ 超電導線材の試作と超電導特性
}

$\begin{array}{llllll}\text { 正員 新 } & \text { 井 } & \text { 和 } & \text { 昭 } & \text { (電総研) } \\ \text { 正 員 } & \text { 立 } & \text { 石 } & & \text { 裕 } & \text { (電総研) } \\ \text { 正員 } & \text { 梅 } & \text { 田 } & \text { 政 } & \text { 一 (電総研) } \\ \text { 正員 } & \text { 我 } & \text { 妻 } & & \text { 洸 } & \text { (電総研) }\end{array}$

New Type of $\mathrm{Nb}_{3} \mathrm{Sn}$ Fiber-Reinforced-Superconductors for High-Field Pulsed Magnet and Effect of Thermal Stress

Kazuaki Arai, Member, Hiroshi Tateishi, Member, Masaichi Umeda, Member, Ko Agatsuma, Member (Electrotechnical Laboratory)

We are developing a new type of superconductor with high elastic modulus fibers for the application of high-field pulsed superconducting magnets, which we call Fiber-ReinforcedSuperconductor(FRS). FRS has great potential for the construction of a $15 \mathrm{~T}$-class pulsed magnet with keeping its size equal to ITER because stainless steels of cable-in-conduit-conductors could be largely reduced.

This paper presents a preparation technique of FRS and its measured superconducting characteristics including strain-Ic relation. FRS has a critical current density of $600\left(\mathrm{~A} / \mathrm{mm}^{2} /\right.$ initial niobium) at $15 \mathrm{~T}$, which is almost equal to one of commercial bronze-processed wires. The intrinsic strain vs. $I_{c}$ characteristics is similar to that of a bronze-processed wire. Thermal strain on FRS are also discussed because materials with high elastic modulus tend to have low thermal contraction which leads to degradation of superconducting characteristics of $\mathrm{Nb}_{3} \mathrm{Sn}$ layer. Possibilities are shown to overcome the degradation with keeping very high elastic modulus of tungsten fiber for reinforcement.

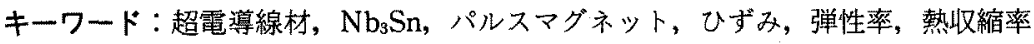

\section{1. まえがき}

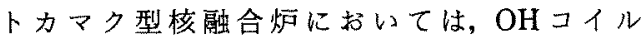
(Ohmic Heating Coil) と呼战れるプラズマを誘導加

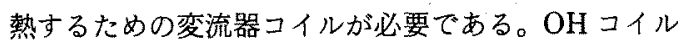
は炬の中心部に置かれ，1秒程度の時間で所定の磁界 を発生するパルスマグネットである。従来 $\mathrm{OH} コ イ$ ルは $7 \mathrm{~T}$ 前後で設計され，合金系の NbTi 用いた パルス超電導マグネットが開発されてきた(1)。しか し，トカマク炉のパルス的な熱負荷を軽隇して準定常 化を図るとともに，炉が過大になることを避けるため に, 近年発生磁束量の增大が要求されるようになって

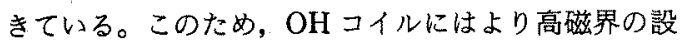

計が採用されつつある。例えば，日本原子力研究所の 次期装置として設計された FERでは $10 \mathrm{~T}$ 級, 日本・ アメリカ・EC・ロシアの国際協力で設計研究が進めら

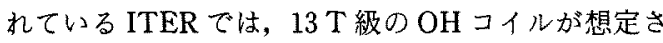
れている。このような流れから, 長期的には更に高磁 界の $15 \mathrm{~T}$ 級の $\mathrm{OH} コ$ イが要求されると考光られる。

$10 \mathrm{~T}$ を超える高磁界を発生するためには，合金系 では，臨界磁界の制限から困難となり， $\mathrm{Nb}_{3} \mathrm{Sn}$ に代 表される化合物系の超電導材料を使用しなければなら ない。しかしながら，よく知られているように化合物 系材料の超電導特性はひずみの印加により低下する。 運転時に発生するフープ灾力により, 導体に大きなひ ずみが加わり, 超電導特性が大きく劣化し, 大型の高 
磁界マグネットではこれが深刻な問題になる。例え ば，ITERの OH コイルを $15 \mathrm{~T}$ 設計にすると，平均 の拡張応力は約 $400 \mathrm{MPa} に$ 達する。このときひず みをブロンズ法 $\mathrm{Nb}_{3} \mathrm{Sn}$ 導体の使用限界の目安である $0.2 \%$ に抑えまうと古ると，ステンレス鋼を使用して も導体断面積の大半を補強材にしなければならず, 超 電導線材の断面積は極めて小さくなるという計算結果 が得られる(2)。導体に占める補強材の割合は, $15 \mathrm{~T}$ を発生するために必要な平均電流密度によって制限さ れるので，このままでは導体の設計が成立しなくな る。ステンレス鋼の弾性率の改善には限界があるの で,ステンレス鋼補強材でこの制限を超えることは困 難である。従って, 導体自身の強度を上げて応力を分 担して，補強材の断面積を少なくする必要がある。ま たパルスマグネットにおいてはヒステリシス損失を 少なくするために, 直流の場合よりも超電等フィラメ ント径を細くしなければならないが, 従来のブロンズ 法による導体では，フィラメント径を細くするにつれ 踟界電流密度が低下してしまうという難点が存在す $b^{(3)}$ 。

このような課題を解決するため, 著者らは図 1 に示 したような瀻維強化型超電導導体 (Fiber-ReinforcedSuperconductor)の研究を進めている(4)。この線材は 中心の高強度繊維と, その周囲に配置された薄膜状の 超電導層加なるフィラメントを基本裱造とする。芯 線㹥高強度かつ高弾性率の緘維であり，フープ応力を 支持し，超電導尿にかかるひずみを小さくする機能を もつ。超電導層としては, 実用線材としての使用実績 が豊富な $\mathrm{Nb}_{3} \mathrm{Sn}$ を採用しているが, 原理的には, $\mathrm{Nb}_{3} \mathrm{Al}$ あるいは酸化物超電導材料など他の材料でも 可能である。超電導艘が薄膜状であるため，低損失の 要請は基本的には満たされている。本論文では, 瀻維 強化型超電導線材の試作方法とその超電導特性につい て述べるとともに，低温における引張試験の結果か ら，本線材が設計思想どおりの機能を発揮することを 明らかにする。

なお，この種の線材としては,ドイツの $\mathrm{KfK}^{(5)}$ アメリカの LLL ${ }^{(6)}$ において, NbNを材料とした研究 が行かれているが， $\mathrm{Nb}_{3} \mathrm{Sn}$ を使用した例は本研究が 初めてである。また，KfKでは材料特性の検討が主 体であり, 補強効果についての研究は行われていな lo

また, 超電導線の強化方法として蛙，ほかにブロン ズ法で作成した多芯線に高強度瀻維を添えることによ って強化する方法(7)，あるいは，マトリックスとして $\mathrm{Cu}-\mathrm{Nb}$ 合金 ${ }^{(8)}$ などを採用することにより，マトリッ
クス自体を強化する方法があるが， $\mathrm{Nb}_{3} \mathrm{Sn}$ フィラメ ントの内部を面接強化する著者らの方法とは異なる。

\section{2. 䋐維強化型超電導線材の試作方法}

〈2・1〉 スパッタリング＼cjkstart瀻維強化型超電導線材 は図 1 に示したように，強化用繊維が電磁力を支える 構造をもつ。強度が高いほど, 破断に強く, また, 弾 性率が高いほど応力によるひずみが小さく，臨界電流 密度の少化を少なくできる。従って, 高強度一高弾性 率の材料を芯線として選択することが重要である。本 論文では, 主にタングステン繊維を強化繊維として採 用した線材について研究を行った。

繊維強化型電導線材は図 2 に示したように, 強化瀻 維上にブロンズ，二オブおよび銅を，逐次スパッタし た後, 真空中での熱処理によって $\mathrm{Nb}_{3} \mathrm{Sn}$ 層を生成さ せるという手法で試作している。図 3 に示すように,

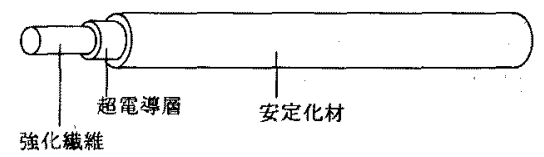

(a) 線材

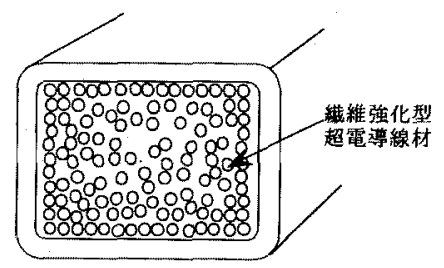

(b) 導体

図 1 緎維強化型超電導線材と導体の概念図. Fig. 1. Fiber-Reinforced-Superconductor (FRS).

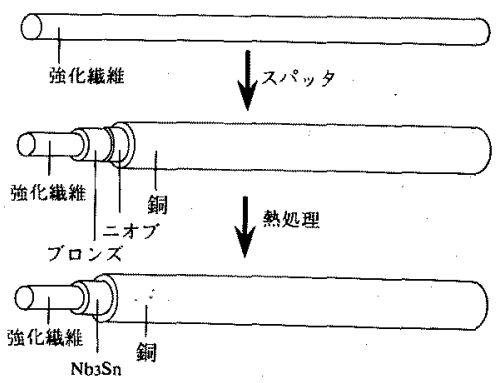

図 2 擮維強化型超電導線材の作成方法 Fig. 2. Preparation of FRS of $\mathrm{Nb}_{3} \mathrm{Sn}$ with rf-magnetron sputtering and post-annealing in vacuum. 


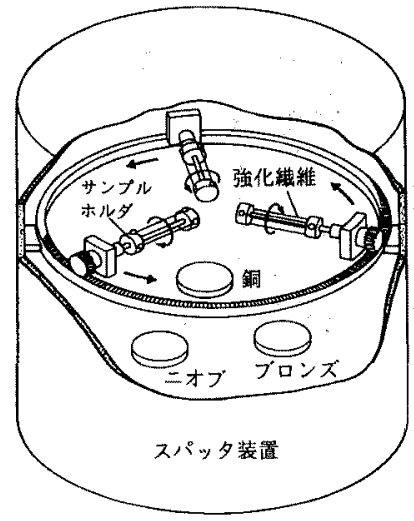

図 3 緎維強化型超電導線材試作用スパッ夕㳖置 Fig. 3. Sputtering chamber for preparation of FRS.

スパッタ装置は真空室内に取付けたサンプルホルダに 強化紻維を固定し，矢印方向にサンプルホルダを自転 一公転運動させることによって，強化瀻維の周囲に均 一にスパッタできるように工夫した。

ターゲットの寸法はプロンズ，二オブ执よび銅とも すべて直径 $76.2 \mathrm{~mm}, 5 \mathrm{~mm}$ 厚である。また，ターゲ ットと基板瀻維の平均的な位置との距離は $75 \mathrm{~mm}$ て ある。スズターゲットはスパッ夕時の発熱で溶けてし まうので(9)，ブロンズターダット(16重量\%スズ)を 用いている。純度は，二オブは $3 \mathrm{~N}$ ，銅とブロンズは $4 \mathrm{~N}$ である。

スパッ夕の手順は次のと怙りである。初めに，チャ ンバ内を $6.7 \times 10^{-4} \mathrm{~Pa}$ 程度に真空引きした後,アル ゴンガスを導入する。アルゴン圧を $0.67 \mathrm{~Pa}\left(5 \times 10^{-3}\right.$ Torr)の一定に保って，スパッタを開始する。まず， ブロンズを，200W の高周波入力で 1 時間スパッ夕 する。次に，二オブを同一条件で 1 時間，最後に安定 化材としての銅も同じ条件で 1 時間スパッ夕する。こ の手順により，ブロンズ中のスズが銅層に拡散するの を避けることができる。

まず，直径 $50 \mu \mathrm{m}$ のタングステン繊維上にブロン ズ，二オブ扔よび銅を上記の条件でスパッタした。次 に，それぞれの膜厚を調べるため，MgO 基板をそれ ぞれのターダットの真上に固定したままブロンズ，二 オブ，銅をこの顳序で同じく 1 時間ずつ上記と同じ条 件でスパッ夕を行った。この断面写真の観察から $\mathrm{MgO}$ 上のブロンズ, ニオブ, 銅のそれぞれの膜厚は $10.2,4.6,8.8 \mu \mathrm{m}$, その比は $2.2: 1.0: 1.9$ であっ

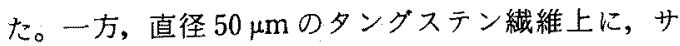

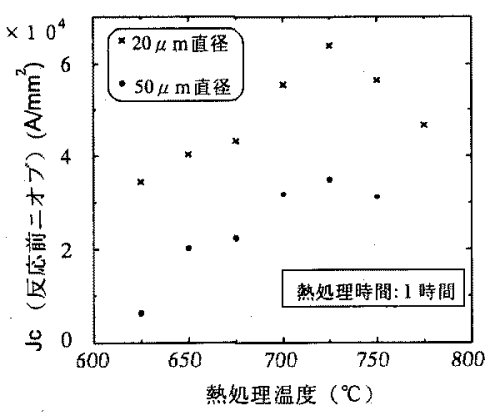

図 4 零磁界中での臨界電流密度と熱処理 温度 (熱処理時間は 1 時間に固定)

Fig. 4. Jc under zero magnetic field versus heat treatment temperature.

ンプルホルダを自転公転させてスパッタした場合，3

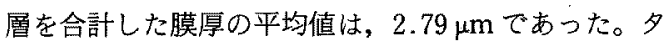

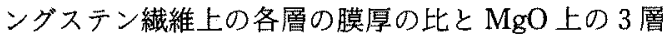
の膜厚の比は等しいと考えられるので，タングステン 繊維上のブロンズ，ニオプ，銅の膜影はそれぞれ 1.2 $\mu \mathrm{m}, 0.55 \mu \mathrm{m}, 1.0 \mu \mathrm{m}$ と見積もられる（スパッタリ ングにより生成された各層の厚さは，原理的には試料 のSEMによる断面観察により決定できる。実際には 図 5 からわかるように，3層の区別が明りょうでない ため,ここで述べたように平面基板上での膜堆積速度 を基に各層の擪さを求めた。

〈2.2〉 熱処理条件の最適化 一般に $\mathrm{Nb}_{3} \mathrm{Sn} の$ 膜 厚が薄いはど，熱処理時間も少なくてすむ(10)。この 線材は二オブの膜厚が $0.55 \mu \mathrm{m}$ と分薄いので，熱 処理時間も短時間で十分であると推定される。そこ て，熱処理時間を 1 時間に固定して，熱処理温度を変 化させて作成した試料について，雾磁界中での反応前 ニオブ当たりの臨界電流密度 $J_{c}$ （臨界電流 $I_{c}$ を反応 前ニオブの断面積で割算した值)を測定した。結果を

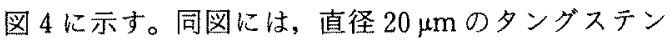
繊維を用いて，同じスパッタ条件と熱処理時間で作成 した瀻維強化型超電導線材の特性も示した。いずれの 場合でも， $725^{\circ} \mathrm{C}$ において $J_{c}$ が最大となっている。 ほかの熱処理時間についても同様に $J_{c}$ を測定した。 しかし，図40最大值以下であったので最適熱処理条 件は $725^{\circ} \mathrm{C} \times 1$ 時間であることがわかった。通常の複 合加工法線材では, $\mathrm{Nb}_{3} \mathrm{Sn}$ 生成させるために 10〜100時間オーダの長時間にわたる熱処理を必要と する。それに対して1時間という短時間の熱処理で $\mathrm{Nb}_{3} \mathrm{Sn}$ が生成できることは，本線材の大きな特徵の 一つである。

図 5(a)，(b)はそれぞれ芯線に直径 $50 \mu \mathrm{m}$ と 20 


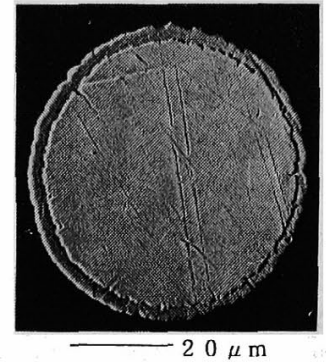

(a) 直径 $50 \mu \mathrm{m}$ のタングステン 䄉維を用いた場合 $\left(725^{\circ} \mathrm{C} \times 1\right.$ 時間の熱好理後 $)$

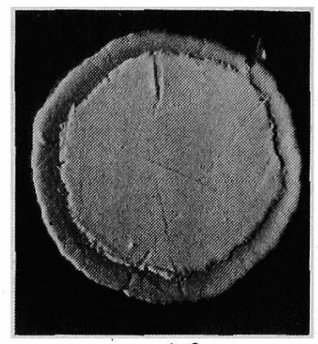

$-10 \mu \mathrm{m}$

(b) 直径 $20 \mu \mathrm{m}$ のタングステン 織維を用いた場合 (熱処理前)

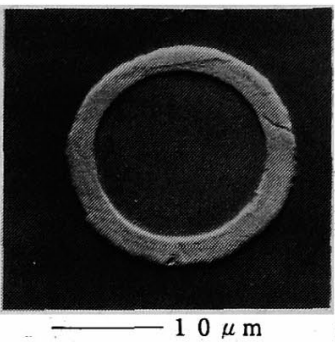

(c) 直径 $15 \mu \mathrm{m}$ のアルミナ 䄉維を用いた場合 (熱処理前)

図 5 各強化繊維を用いた繊維強化型超電導線材の断面の SEM 写真

Fig. 5. SEM examination of cross section of FRS with different reinforcing fibers.

$\mu \mathrm{m}$ のタングステン繊維を用いた䋗維強化型超電導線 材の断面 SEM 写真である。それぞれの写真の中心に タングステン繊維, その周囲にスパッタされた薄膜層 があることがわかる。（c）図は, 芯線の表面の滑らか さと生成膜の滑らかさを比較するため,アルミナ繊維 （直径 $15 \mu \mathrm{m}$ ）にタングステンの場合と同様の条件で スパッタしたものである。アルミナ繊維の表面が滑ら かであることを反映して, 生成層もタングステンの芯 線の場合に比べて均質である。従って，表面の滑らか な芯線を用いれば, $\mathrm{Nb}_{3} \mathrm{Sn}$ 層も滑らかであると考え られる。アルミナ繊維はタングステンに比べて強度, 弾性率などは劣るものの, アルミなどの金属の強化緎 維としても使われている高強度綫維であり, タングス テンと異なり絶縁物であることが一つの特徴である。

\section{3. 超電導特性の測定結果}

〈3・1〉 緎維強化型超電導線材の臨界電流密度の磁 界依存性直径 50, 40, および $20 \mu \mathrm{m}$ のタングス テンを用いてそれぞれについてブロンズ, ニオブ, 銅 の3 層を前章と同じ条件でスパッタおよび熱処理を行

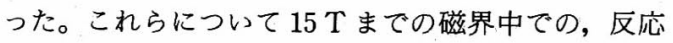
前ニオブ当たりの臨界電流密度 $J_{c}$ の特性を図 6 に示 す。同図には Airco 社のブロンズ法線材のデータも 示しているが(11), 直径 $20 \mu \mathrm{m}$ のタングステンの場合 はほぼこれに近い特性が得られていることがわかる。 最近の $\mathrm{Nb}_{3} \mathrm{Sn}$ 系の線材では, 安定化銅を除いた臨界 電流密度として, $15 \mathrm{~T}$ に抢いて, $650 \mathrm{~A} / \mathrm{mm}^{2}$ 程度の 值が達成されている(12)。著者らの線材では, これは 強化繊維と反応前の銅を含めない, 寸なわち反応前の ニオブとブロンズ量当たりの臨界電流密度に相当する が, 直径 $20 \mu \mathrm{m}$ のタングステン繊維を用いた場合,

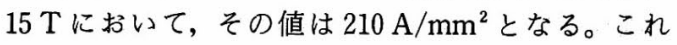

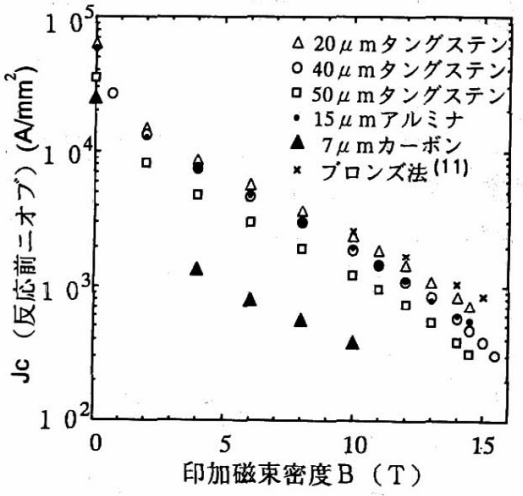

図 6 臨界電流密度の磁界特性

Fig. 6. $J_{c}$ versus $B$ for FRS.

は, $650 \mathrm{~A} / \mathrm{mm}^{2}$ の $1 / 3$ 以下の值であるが第三元素の 添加あるいは〈4・5〉節で述べる方法などによって改 善可能であると考えられる。

図 6 には, 直径 $15 \mu \mathrm{m}$ のアルミナ繊維と直径 $7 \mu \mathrm{m}$ のカーボン纎維を用いた繊維強化型超電導線材の $J_{c^{-}}$ $B$ 特性も示している。それぞれ，タングステンの場 合と同じ条件でスパッタした後, $725^{\circ} \mathrm{C} \times 1$ 時間の熱 処理を加えて作成したものである。アルミナは $40 \mu \mathrm{m}$ 直径のタングステンの場合と同様の $J_{c}-B$ 特性を示す が, カーボン繊維の場合は, 直径 $20 \mu \mathrm{m}$ のタングス テンと比較して一桁程度低い值である。この点につい ては〈4・1〉節でその原因を考察する。

\section{〈3・2〉 織維強化型超電導線材の単軸引張特性}

既に述べたように, 繊維強化型超電導線材の基本概 念は線材に加わる長手方向の応力を, 高強度繊維によ って支持することにより, 超電導層にかかる引張ひず みを小さくしようとするものである。この設計思想の 


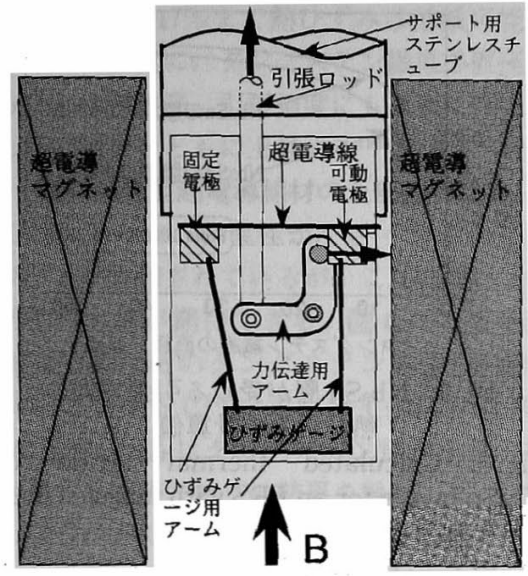

図 7 超電導線用引張試験装置

Fig. 7. Schematic diagram of the highfield apparatus used to measure $I_{c}(B, \varepsilon)$.

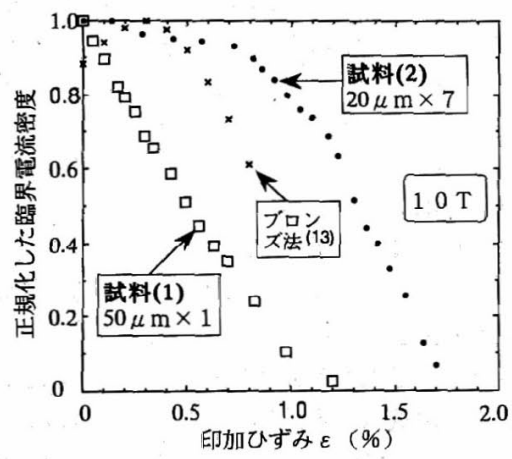

図 8 印加ひずみと臨界電流密度

Fig. 8. Critical current density normalized by the maximum value as a function of applied uniaxial tensile strain.

妥当性を検証するためには，実際に応力が印加された 状態で線材の超電導特性がどのように変化するかを調 ベる必要がある。従来の緎維強化型超電導線材の研究 例では，このような応力下での特性測定はまだ行われ ていない。

図 7 は測定に用いた引張試験装置の模式図である。 超電導線は，電極にはんだによって固定されている。 左の電極は固定されており, 引張ロッドを知印で示し た方向に引き上げると, その力が力伝達用アームを経 由して右側の可動電極を右方向へ動かす。この電極の 変位はひずみゲージにより測定する。ひずみゲージ は, 室温での校正がそのまま, 液体へリウム中での温 度でも校正值が変化しない変位計 (MTS 社製)を使用
した。

次の 2 種類の試料について, 液体へリウム中におい て, $10 \mathrm{~T}$ の印加磁束密度のもとで, 引張試験を行っ た。

試料( 1 ) は直径 $50 \mu \mathrm{m}$ のタングステンを芯線にし た繊維強化型超電導線材である。製作条件は前述の第 2 章に示したとおりである。試料(2)は直径 $20 \mu \mathrm{m}$ のタングステン 7 本を $2 \mathrm{~cm}$ ピッチで撚りを施し, こ れも同様に，第 2 章の製作条件で試作した無含浸の撚 線である。この 2 種類の試料について行った引張試験 の結果を図 8 に示す。䋛軸は最大値で規格化した $J_{c}$ である。直径 $50 \mu \mathrm{m}$ タングステン 1 本のみを芯線に 用いた試料 (1)の $J_{c}$ は単調に減少する特性を示す。 同図には従来のブロンズ法線材の典型的なひずみ特性 を比較のため示してある(13)。

\section{4. 超電導特性の測定結果の検討}

〈4・1〉タングステン, アルミナおよびカーボン緎 維を用いた繊維強化型超電導線材の $\boldsymbol{J}_{c}-\boldsymbol{B}$ 特性の比較

図 6 によると,カーポン繊維を芯線とした試料の $J c$ は，タングステン繊維およびアルミナ繊維を芯線 とした試料の $J_{c}$ に比べてかなり低い值である。芯線 が $J_{c}$ に影響を与える要因として，芯線と $\mathrm{Nb}_{3} \mathrm{Sn}$ との 熱収縮率の違いから， $4.2 \mathrm{~K}$ までの冷却に扔いて，芯 線が $\mathrm{Nb}_{3} \mathrm{Sn}$ 層に熱的なひずみを加えることが予想さ れる。使用したカーボン纎維の室温中での熱収縮率は $0.7 \times 10^{-6}(1 / \mathrm{K})$ であるが, タングステンは $4.5 \times 10^{-6}$ $(1 / \mathrm{K})$, アルミナは $5.4 \times 10^{-6}(1 / \mathrm{K}), \mathrm{Nb}_{3} \mathrm{Sn}$ は 7.2 $\times 10^{-6}(1 / \mathrm{K})$ である(ただし，アルミナの値は $100 \%$ $\mathrm{Al}_{2} \mathrm{O}_{3}$ の値であって, 使用したアルミナ織維は $\mathrm{Al}_{2} \mathrm{O}_{3}$ $85 \%, \mathrm{SiO}_{2} 15 \%$ の組成であるので，おそらくこの值と は一致しないが，一つの目安として考えられる。ま た, タングステン, アルミナおよび $\mathrm{Nb}_{3} \mathrm{Sn}$ の值は, $293 \mathrm{~K}$ におけるものである(14))。カーボン瀻維だけが $\mathrm{Nb}_{3} \mathrm{Sn}$ より一桁程度低い熱収縮率であるのに対して, タングステンとアルミナは $\mathrm{Nb}_{3} \mathrm{Sn} に$ 近い特性を示し ている。この 3 種類の芯線を比較するには, 厳密には 各芯線と芯線に密着しているブロンズとの反応性も調 べなければならないが, カーボン織維の熱収縮係数が これだけ低いことから, カーボン纎維を採用した繊維 強化型超電導線材の $\mathrm{Nb}_{3} \mathrm{Sn}$ 層には, タングステンあ るいはアルミナに比べて大きな熱的ひずみが動いてい るので, 主にこれにより $J_{c}$ が劣化したと推定できる。 これから, カーボン織維は, 高弾性率という点は有利 であるが, 熱収縮率の点で繊維強化型超電導線材の芯 線として採用は困難と考えられる。 
〈4・2〉 $\mathbf{N b}_{3} \mathbf{S n}$ に作用する熱ひずみの計算 タン グステンの弾性率は約 $400 \mathrm{GPa}$ であるが，アルミナ の約 $210 \mathrm{GPa}$ 上りはるに高い。従って，これ以降 はタングステンを繊維強化型超電導線材の芯線として 用いることを中心に議論を進める。タングステン緘維 あるいはカーボン織維のように，400 GPa を超える高 弾性率の材料は，熱収縮率が， $\mathrm{Nb}_{3} \mathrm{Sn}$ より小さいも のが多い。従って，これらを芯線に採用した繊維強化 型超電導線材の $\mathrm{Nb}_{3} \mathrm{Sn}$ 層は $4.2 \mathrm{~K}$ まで朎却すると, 線方向に引張的な熱ひずみを受ける結果となる。

本節では，試作したタングステンを用いた瀻維強化 型超電導線材について，熱ひずみを定量的に推定す る。つまり, 熱処理温度の $1,000 \mathrm{~K}$ から液体ヘリウム 温度の $4.2 \mathrm{~K}$ までの冷却過程で, $\mathrm{Nb}_{3} \mathrm{Sn}$ 層が受ける 熱ひずみを計算する（熱処理温度 $725^{\circ} \mathrm{C}$ は $1,000 \mathrm{~K}$ と 近似した）。熱処理時にブロンズ中のスズはすべてニ オブと反応し，熱処理後の線材はタングステン，銅， $\mathrm{Nb}_{3} \mathrm{Sn}$ で構成されていると仮定する。タングステン, 銅， $\mathrm{Nb}_{3} \mathrm{Sn}$ の断面積をそれぞれ $S_{w}, S_{c}, S_{s}$ とおき， それぞれが受ける内部応力を $\sigma_{w}, \sigma_{c}, \sigma_{s}$ とする。瀻維 強化型超電導線材に外力が働かない場合, 線方向の力 のバランスから次式が成立する。

$$
S_{w} \sigma_{w}+S_{c} \sigma_{c}+S_{s} \sigma_{s}=0
$$

繊維強化型超電導線材の $1,000 \mathrm{~K}$ に扔ける長さを $L_{a h}$ とする。 $\mathrm{Nb}_{3} \mathrm{Sn}$ およびタングステンの長さも $L_{a h}$ に 等しい。 $4.2 \mathrm{~K} に$ 抢けるフィラメント線材の長さを $L_{a l}$ とおく。瀻維強化型超電導線材の $\mathrm{Nb}_{3} \mathrm{Sn}$ 単体が 㐫力ゼ口の状態で, $1,000 \mathrm{~K} \rightarrow 4.2 \mathrm{~K}$ に冷却されたと きの長さを $L_{s t}$ とすると,

$$
L_{s t}=L_{a h}-C_{s} L_{a h}
$$

となる。ここで, $C_{s}$ は $\mathrm{Nb}_{3} \mathrm{Sn}$ 単体が応カフリーの状 態で, $1,000 \mathrm{~K}$ から $4.2 \mathrm{~K}$ まで温度が変化するとき の, 全長に対する熱収縮分の割合である（線膨張係数 $\alpha$ を $4: 2 \mathrm{~K}$ から $1,000 \mathrm{~K}$ まで積分したものがC 6 に等 しい)。従って, 温度 $4.2 \mathrm{~K}$ における繊維強化型超電 導線材中の $\mathrm{Nb}_{3} \mathrm{Sn}$ の熱ひずみ $\varepsilon_{s l}$ は，

$$
\begin{aligned}
\varepsilon_{s l} & =\left(L_{a t}-L_{s l}\right) / L_{s l} \\
& =L_{a l} /\left\{\left(1-C_{s}\right) L_{a h}\right\}-1
\end{aligned}
$$

となる。タングステン単体が応力フリーの状態で, $1,000 \mathrm{~K}$ から $4.2 \mathrm{~K}$ まで温度が変化するときの, 全長 に対する熱収縮分の割合を $C_{w}$ とし，また織維強化型 超電導線材のタングステン単体が熱ひずみを受けない と仮定したときの $4.2 \mathrm{~K}$ に冷却されたときの長さを $L_{w i}$ とすると, フィラメント線材中の $4.2 \mathrm{~K}$ に扔ける タングステンの熱ひずみ $\varepsilon_{w l}$ は同様に,

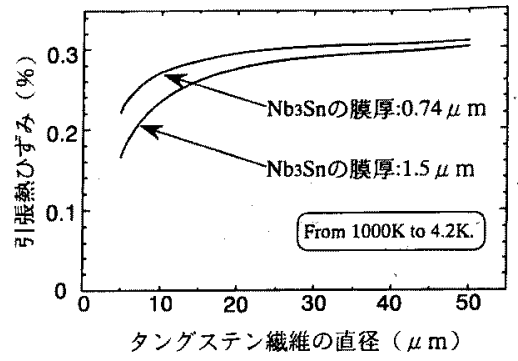

図 $9 \mathrm{Nb}_{3} \mathrm{Sn}$ 層が受ける引張方向の 熱ひずみの計算值

Fig. 9. Calculated thermal strain on $\mathrm{Nb}_{3} \mathrm{Sn}$ layers for an FRS with tungsten fiber.

$$
\begin{aligned}
\varepsilon_{w l} & =\left(L_{a l}-L_{w l}\right) / L_{w l} \\
& =L_{a l} /\left\{\left(1-C_{w}\right) L_{a h}\right\}-1
\end{aligned}
$$

となる。タングステンと $\mathrm{Nb}_{3} \mathrm{Sn}$ は弾性領域内にある, つまり $\sigma=\varepsilon E$ の式を適用できるとする。弾性率をそ れぞれ $E_{w}, E_{s}$ とおくと，(1)，(3)，(4)を用いて

$$
\varepsilon_{s l}=\frac{1}{1-C_{s}} \frac{S_{w} E_{w}+S_{s} E_{s}-S_{c} \sigma_{c}}{\frac{S_{w} E_{w}}{1-C_{w}}+\frac{S_{s} E_{s}}{1-C_{s}}}-1
$$

が得られる。ここでは, フィラメント線材中の銅は冷 却過程において塑性変形するので $\sigma_{c}=21 \mathrm{MPa}$ 一定と おいた(15)。また, $E_{w}=400 \mathrm{GPa}, E_{s}=165 \mathrm{GPa}, C_{s}$ $=0.0074^{(15)}, C_{w}=0.00424^{(14)}$ とした。 $\mathrm{Nb}_{3} \mathrm{Sn}$ の膜厚 は初期ニオブが全量 $\mathrm{Nb}_{3} \mathrm{Sn}$ に反応したと仮定した理 想体積膨張を考慮し, 初期ニオブの 1.3 倍の $0.74 \mu \mathrm{m}$ とした。作成したフィラメント線材の $\mathrm{Nb}_{3} \mathrm{Sn}$ の 4.2 Kにおける引張熱ひずみ $\varepsilon_{s l}$ の計算結果を図 9 に示 す。タングステンの直径が小さくなるに従って引張熱 ひずみは小さくなる傾向を示している。図 6 におい て,タングステンの直径が小さくなるにつれて $J_{c} か ゙$ 向上しているが, これは引張ひずみが小さくなったか らであると考えられる。

タングステン繊維は直径数百 $\mu \mathrm{m}$ から直径 $5 \mu \mathrm{m}$ ま での種々のサイズの織維が量産されているが, 現在, 著者らのところでは，極端に細い線は取扱いが難しい ので直径 $20 \mu \mathrm{m}$ までのものしか扱っていない。今後 は, 更に小さい直径のタングステン織維を用いて瀻維 強化型超電導線材を作成し, その効果を確認する予定 である。図 9 に示したように，5 $\mathrm{m}$ では約 $0.22 \%$ ま で熱ひずみを低隇できることが予想される。同図には $\mathrm{Nb}_{3} \mathrm{Sn}$ の膜厚が枕よそ倍の $1.5 \mu \mathrm{m}$ の場合についての 計算結果も示した。 $\mathrm{Nb}_{3} \mathrm{Sn}$ の膜厚を倍にすると, 引 張熱ひずみは更に低減され，タングステンの直径が 
$5 \mu \mathrm{m} に な る と$ 約 $0.17 \%$ まで熱ひずみは低減可能であ ると計算された。更に，タングステン織維の直径が小 さくなることは弾性率, 引張強度にも有利に作用し, 両者とも径の減少とともに上昇する(16)。

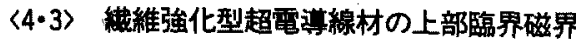

前節て述べたとおり，直径が小さくなるのに従つ て，熱ひずみが緩和されているが，これに伴い上部臨 界磁界 $B$ c2 20,40 および $50 \mu \mathrm{m}$ のタンダステンの $J_{c}-B$ 特性を クレーマープロットし(17), 求めた上部臨界磁界 $B_{c 2}^{*}$ を図 10 に示す。 $B_{c 2}^{*}$ はタングステン径が小さくなる に従い向上する期待どおりの結果を得た。

岩手大学らのグループは，タンタルを高磁界，大型 マグネット用導体の強化材として使うための研究を進 めているが，機械的な強化材の機能だけではなく，電 気的な安定材としても使えることを指摘してい る(18)。また，タンタルはタングステンに比べると弾 性率は $186 \mathrm{GPa}^{(15)}$, 引張強度は $950 \mathrm{MPa}^{(19)}$ と落ちる が，熱収縮率はタングステンと比較すると， $\mathrm{Nb}_{3} \mathrm{Sn}$ に近い $(1,000 \mathrm{~K} \rightarrow 4.2 \mathrm{~K}$ の熱収縮量は $0.61 \%$, $\mathrm{Nb}_{3} \mathrm{Sn}$ は 0.74\%)。そこで，タングステンの場合と同 じ条件で，直径 $50 \mu \mathrm{m}$ のタタル線を用いて纎維強 化型超電導線材を試作した。この線材のB光は $22 \mathrm{~T}$ という直径 $50 \mu \mathrm{m}$ のタングステンの場合に比べてた いへん高い値を得た。 $\mathrm{Nb}_{3} \mathrm{Sn}$ にかかる線方向の熱ひ ずみは（5)式を用いて計算すると $0.103 \%$ とングス テンの場合に比べて小さな引張熱ひずみであった。こ のタンタル線を用いた繊維強化型超電導線材はタング ステン線の場合と同一のスパッ夕条件, 熱処理条件で 作成しているから， $\mathrm{Nb}_{3} \mathrm{~S} \mathrm{~S} の$ 微紐組織は同じである と仮定されるので， $B_{c 2}^{*}$ の上舁は引張熱ひずみが少な

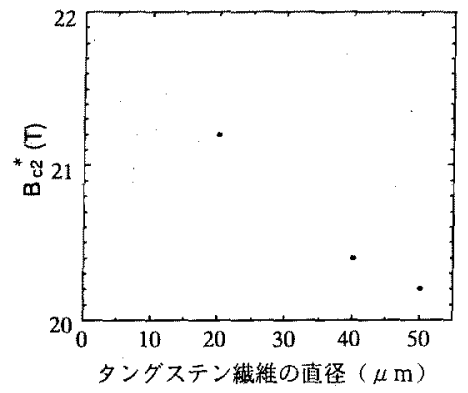

図 10 上部臨界磁界とタングステン 絨維の直径

Fig. 10. Upper critical field $B_{c 2}^{*}$ vs. diameter of tungsten fiber. $B_{c 2}^{*}$ is estimated from critical current density with Kramer's plot.
いことが要因であると思われる。このように熱収縮率 が $\mathrm{Nb}_{3} \mathrm{Sn} に$ に近い芯線を用いると，熱ひずみが減少す るので特性は向上する。本論文では，高強度一高弹性 率という要素を重視してタンダステン芯線の場合を中 心に検討しているが，タンタル線のこの特性は本章の 熱ひずみの解析結果の正しきを傍証するものと考えら れる。

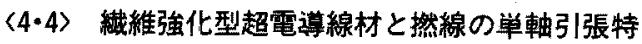
性通常のブロンズ法線材は， $\mathrm{Nb}_{3} \mathrm{Sn}$ より熱収縮 率が大きいブロンズが，㳸体へリウム温度まての冷却 の過程で $\mathrm{Nb}_{3} \mathrm{Sn}$ に王縮的な熱ひずみを与えている。 印加ひずみを０の状態から次第に上昇させると，ある ひずみてこの熱ひずみが緩和され，蹊界電流密度は極 大値をとる。

図 8 において，ブロンズ法(13) の線材は $0.3 \%$ で極 大值を示し, $\mathrm{Nb}_{3} \mathrm{Sn}$ に働く線方向の真のひずみが 0 となる。〈4・2〉節で述べたように, 繊維強化型超電導 線材の $\mathrm{Nb}_{3} \mathrm{Sn}$ は冷却により压縮熱ひずみではなく逆 に引張熱ひずみを受けているため，図 8 に示した試料 （1）に見られるように，Jc 㳊引張ひずみの增加とと もに単調に滅少する特性を示し，ブロンズ法に見られ る極大点をもたない。図 9 から, 試料(1)0舎径 $50 \mu \mathrm{m}$ のタングステン纎維を用いた瀻維強化型超電導 線材は，印加ひずみゼ口の状態で $\mathrm{Nb}_{3} \mathrm{Sn}$ は 0.308\% の引張熱ひずみを受けている，すなわち，図 8 に朊い て，引張ひずみ 0 のときに，真のひずみは引張方间に $0.308 \%$ ある。試料(1)とブロンズ法のデータを, 真のひずみを横軸にとって整理し直した結果を网 11 に示す。試料(1)と従来のブロンズ法線材とを比較す

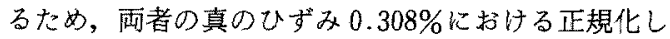
た臨界電流密度が等しいと仮定した。真のひずみが

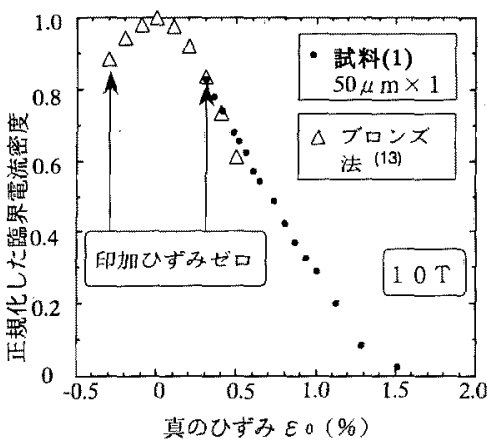

図 11 真のひずみと臨界電流密度 Fig. 11. Normalized critical current density as a function of intrinsic strain $\varepsilon_{0}$. 
$0.3 \%$ から $0.5 \%$ で筙囲では，ほほ同じ特性を示 している。若干のずれは，線材の構成が異なるためで あると考えられる(20)。試料（1）において真のひずみ 0.308\%以下については印加ひずみは生縮方向になる ので測定は難しい。これらの結果から, 瀻維強化型超 電導線材のひずみ特性は真のひずみで考えると, ブロ ンズ法線材の特性とほ活司じであると推定される。こ れらのデータを基にして, 繊維強化型超電筫線材を用 いて 15 Tクラスのパルスマグネットを概念設計した 場合, 電流密度を〈3・1〉節に扔いて試作した $J_{c}$ の2 倍 程度に確保できれば，15 T の動作点において $\mathrm{Nb}_{3} \mathrm{Sn}$ に働く印加ひずみを $0.2 \%$ 程度に収めることが可能で ある，という計算結果を得た(2)。この達成すべき $J_{c}$ は，〈3・1〉節に扔いて述へたように，実現可能である と考えられる。従って, 基本的には織維強化型超電導 線材の設計思想が成立することが示された。

図 8 において，試料(2)は無含浸の撚線のデータで あるが，試料(1)あるいはブロンズ法のデータと比較 すると、ひずみの增加の割にJ $J_{C}$ の低下が少ない。こ れはおそらく無含浸であるため, 撚りの緩みが, 引張 力の増加とともに締まるからで，線材の単軸方向に働 く奉質的な引張ひずみ妙ないと推測される。0\%か ら0.7\%あたりまでが、この領域であると思われる。 1.2\%を超えたところについては試料( 2 )の $J_{c}$ の呧下 の早さは，試料（1）における0\%から1\%付近のそれ とほ泟同等である。正磪な此較を行うためには, 面径 $50 \mu \mathrm{m}$ のタングステンを用いて撚線線材を作らなけれ ばならないが, 䋐維強化型超電導線材の撚線線材は, 单芯線と同等あるいはそれ以上のひずみ特性を示すこ とを示惨している。

〈4・5〉タングステンを用いた織維強化型超電導線 材の特性向上について タングスデンあるいはカー ボン㵶維のように，400 GPa を超える非常に高い弾性 率をもつ材料は，熱収縮率が低い傾向にある。帡っ て、このような繊維を採用した繊維強化型超電導線材 は，外部からの引張力が印加したときのひずみは少な いが, 外力が0でも，〈4・2〉節で述べたとたり， $\mathrm{Nb}_{3} \mathrm{Sn}$ 層は線方向に引張ひずみを受けた状態になっ ている。熱収縮率を基準に考えて, 別の材料を芯線に 採用することも可能であるが, タングステンの高強度高弾性率という性質を生かしつつ, 熱収縮率の問題を 含めて, その特性向上を図ることは, 緎維強化型超電 導線材の基本理念にかなった考え方であると考えられ る。そこで, 以下に，タングステンを用いた繊維強化 型超電導線材の特性の向上策をあげる。

(1) $\mathrm{Nb}_{3} \mathrm{Sn} へ$ Ti などの第三元素の添加
(2).タングステンの体䅡率を小さくする

(3) タングステンの緎維を焼鈍する

（4）タングステンに不純物を加える

（1）は，商用ブロンズ法で広く行われてお゙り， $\mathrm{Nb}_{3} \mathrm{Sn}$ の材料自体の $J_{c}$ を殁る方法である。（2）について は,〈4・2〉節で述べた。（3）は，タングステン織維は 焼鈓することによりその線脚張係数を変化させること が可能で，焼鍍温度を上げるほど熱收縮率は大きくな ることが報告されている(16) のて，スパッ夕前にタン

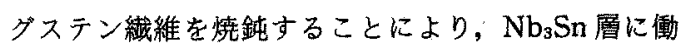
く熱ひずみを軽減できる。

(4)については，その一例として，タングステンに レニウムを添加する方法が考えられる。文献(21)に

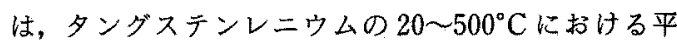
均的な熱収縮率が揭載されているのて，これを引用す ると，純粋なタングステンは $4.66 \times 10^{-6}(1 / \mathrm{K})^{(14)}$, $3 \%$ ウウムを含んだ $97 \% \mathrm{~W}-3 \% \operatorname{Re}$ は $4.84 \times 10^{-6}(1 /$ $K)^{(21)}, 75 \% \mathrm{~W}-25 \% \operatorname{Re}$ は $5.08 \times 10^{-6}(1 / \mathrm{K})^{(14)}, 74 \%$ $\mathrm{W}-26 \% \operatorname{Re} 1.06 \times 10^{-6}(1 / \mathrm{K})^{(21)}$ である。レニウム の割会を増加させるに従って，熱収縮率は堌加し，同 じく20 $500^{\circ} \mathrm{C}$ における $\mathrm{Nb}_{3} \mathrm{Sn} の$ 平均的な熱收縮率 $8.24 \times 10^{-6}(1 / \mathrm{K})^{(14)}$ に接近しつつある。これは，夕 ングステンレニウム中のレニウムの含有率を增やす と, 織維強化型超電導線材の $\mathrm{Nb}_{3} \mathrm{Sn}$ に㗢く熱ひずみ を少なくすることができることを示している。残念な がら，26\%を超えるレニウムを添加した場合の熱収縮 率のデータ拉よび極低温における熱收縮率のデータが そろっていないので，断言はできないが，レニウムの 含有率を適切に選ぶことによって， $\mathrm{Nb}_{3} \mathrm{Sn}$ に働く熱 ひずみをゼロにできる可能性が考えられる。すなわ ち，熱ひずみに伴う $J_{c}$ の低下をゼロにできる，タン グステンを用いた高強度ー高弾性率の繊維強化型超電 導線材の可能性が示唆された。またレニウムの添加 は弾性率および引張強度も向上する効果があり(21), タングステンの高強度-高弾性率の性能を失うことは ない。タングステンに添加する材料として，レニウム が最適であるかどうかは，今後の研究によって決まる が,このように不純物を加える方法が有効であること が示された。

\section{5. 結 論}

15 T級高磁界パルス超電導マグネットへの適用を 目標として，瀻維強化型 $\mathrm{Nb}_{3} \mathrm{Sn}$ 超電䀤線材を試作し た。臨界電流密度の磁界特性，ひずみ特性を測定する とともに，熱ひずみの影響について考察した。本研究 により得られた主要な結論は以下のとおりである。 
（1）スパッタリング装置を用いて繊維強化型 $\mathrm{Nb}_{3} \mathrm{Sn}$ 超電導線材を, タングステン繊維, アルミナ 擮維, カーボン瀻維を用いて試作した。直径 $20 \mu \mathrm{m}$ のタングステン繊維を用いた線材はブロンズ法による 商用線材に近い臨界電流特性を示した。

（2）タングステン緘維の直径をパラメータにして 臨界電流密度 $J_{c}$ の磁界依存性を測定するとともに, クレーマプロットにより上部臨界磁界 $B_{c 2}^{*}$ を評価し た。その結果, 繊維の直径が小さくなるほど, $B_{c 2}^{*}$ の 向上に伴う, $J_{c}-B$ 特性の向上が見られた。

（3）熱収縮率の影響を明らかにするため, $\mathrm{Nb}_{3} \mathrm{Sn}$ に働く熱ひずみを計算によって求めた。芯線の直径を $5 \mu \mathrm{m}$ に, かつ, $\mathrm{Nb}_{3} \mathrm{Sn}$ 層の厚さを現状の倍にするこ とによって, 直径 $50 \mu \mathrm{m}$ のタングステン上の $\mathrm{Nb}_{3} \mathrm{Sn}$ 層の熱ひずみを半分近くまで低減できることを示し た。また，タンタル絨維を用いた緎維強化型超電導線 材を試作し, 熱収縮率が $\mathrm{Nb}_{3} \mathrm{~S} n$ に近いことによる, $B_{c 2}^{*}$ の向上がみられた。

（4）繊維強化型超電導線材の引張試験を行い, $\mathrm{Nb}_{3} \mathrm{Sn}$ の真のひずみは, 従来のブロンズ法と同様の

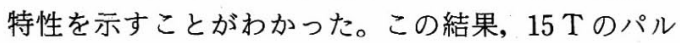
スマグネットの可能性, および繊維強化型超電導線材 の設計思想が成立することが示された。

（5）無含浸の繊維強化型超電導撚線の引張試験を 行った。撚線の臨界電流密度対ひずみ特性は, 素線と 同じ，あるいは，それ以上の特性をもつことが示唆さ れた。

（6）タングステン中に不純物を加えることによ り, タングステンの弾性率を低下させることなく, $\mathrm{Nb}_{3} \mathrm{Sn}$ に働く熱ひずみに伴う $J_{c}$ の低下がない, 緘維 強化型超電導線材の可能性が示唆された。

終りに，本研究の機会をいただくとともに，暖かい 御支援を賜った, 名古屋工業技術試験所長（元電子技 術総合研究所エネルギー部長) 富山朔太郎博士, 電子 技術総合研究所極限技術部長 木村錫一博士（前エネ ルギー部長), 同現エネルギー部長 大西利只博士に厚 く感謝の意を表します。また, SEM 観察に際し御協 力をいただいた電子技術総合研究所根岸 明主任研 究官および(株)フジクラ定方伸行氏, ならびにアルミ ナ絾維について御協力をいただいた(株)住友化学工業 山蔦浩治氏に深く感謝の意を表します。

(平成 4 年 7 月 21 日受付)

\section{文献}

（1）立石・大西・小室・小山：「アルミ安定化超電導線を用いた $3 \mathrm{MJ}$ パルス超電導マグネットの設計製作と通電特性」, 電学

電学論A, 113 巻 1 号, 平成 5 年

昭和 36 年 1 月 24 日生。 58 年横浜国 立大学電気工学科卒業。同年 4 月電子技 術総合研究所入所。周波数解析に関する 研究および超電導の応用, 低温工学に関 する研究に従事。現在, 核融合用パルス超電導マグネット

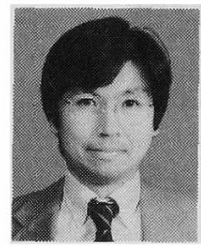

新井和昭 (正員) に関する研究を行っている。低温工学協会会員。

(2) 立石・我妻・新井: 「内部強化型超電導線材を用いた 15 个級 パルスマグネット用導体の概念設計」, 平 4 低温工学・超電導 学会春季発表会, 54

(3) G. Rupp, K. Wohlleben \& E. Springer: "Filament-Size Dependent Critical Current of Multifilamentary $\mathrm{Nb}_{3} \mathrm{Sn}$ Conductors", IEEE Trans. Magnetics, Mag-17, No. 5, 1622 (1981)

(4) K. Arai, H. Tateishi, K. Agatsuma \& T. Onishi: "Development of Internally Reinforced Superconductor for High Field Pulsed Magnet", 3rd International Toki Conference (1991).

5) M. Dietrich: "Microstructure and Internal Strain Control in NbN on Carbon Fibers", IEEE Trans. Magnetics, Mag-21, No. 2, 455 (1985)

(6) L. T. Summers, et al.: "The Influence of Liquid Metal Infiltration on the Superconducting Characteristics of Niobium Nitride", Adv. Cryog. Eng. Materials, 34, 835 (1988)

7) R. Flükiger, E. Drost, \& W. Specking: "Effect of Internal Reinforcement on the Critical Current Density of $\mathrm{Nb}_{3} \mathrm{Sn}$ wires", ibid., 30, 875 (1984)

（8）渡辺・後藤・斉藤・河野：「複合強化型 $\mathrm{Nb}_{3} \mathrm{Sn}$ 超電導線材の 特性」, 平 3 低温工学・超電導学会春季発表会, 304

(9) R. T. Kampwirth, J. W. Hafstrom \& C. T. Wu: "Application of High Rate Magnetron Sputtering to the Fabrication of A-15 Compounds", IEEE Trans. Magnetics, Mag13, No. 1, 315 (1977).

(10) N. J. Pugh, et al.: "Microstructure Development in Composites", ibid., Mag-21, No. 2, 1129 (1985)

(11) D. R. Dietderich, et al. : "The Critical Current Density and Microstructural State of an Internal Tin Multifilamentary Superconducting Wire", ibid., Mag-21, No. 2, 297 (1985)

(12) G. M. Ozeryansky \& E. Gregory: "A New Internal Tin $\mathrm{Nb}_{3} \mathrm{Sn}$ Conductor Made by a Novel Manufacturing Process", ibid., 27, No. 2, 1755 (1991)

(13) J.W. Ekin: "Strain Effects in Superconducting Compounds", Adv. Cryog. Eng. Materials, 30, 823 (1984)

(14) Y.S. Touloukian, et al.: Thermophysical Properties of Matter, Vol. 12 (1975) IFI/Plenum

(15) D. S. Easton, et al.: "A Prediction of the Stress State in $\mathrm{Nb}_{3} \mathrm{~S}$ n Superconducting Composites", J. Appl. Phys. 51, No. 5, 2748 (1980)

(16) C. J. Smithells: Tungsten (1952) Chapman \& Hall LTD

(17) E. J. Kramer: "Scaling Laws for Flux Pinning in Hard Superconductors", J. Appl. Phys., 44, No. 3, 1360 (1973)

(18) M. Matsukawa, et al.: "Heavily Cold Worked HighPurity Ta as a Reinforcing Stabilizer", IEEE Trans. Magnetics, 28, No. 1, 880 (1992)

(19) 理科年表 (平 4) 丸善

(20) K. Katagiri, et al. : "Strain Effect in an Internally Stabilized Multifilamentary ( $\mathrm{Nb}, \mathrm{Ti})_{3} \mathrm{Sn}$ Superconducting wire", Adv. Cryog. Eng. Materials, 36, 85 (1990)

(21) Plansee 社: “Wolfram Tungsten Tungstene", Plansee 社 の技術資料 


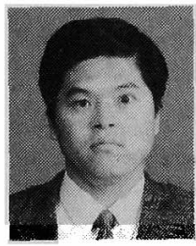

立 石 裕 (正員)

昭和 30 年 7 月 6 日生。 54 年東京大学 理学部物理学科卒業。同年電子技術総合 研究所入所。現在, エネルギー部超電導 応用研究室主任研究官。主として，核融 合用パルス超電導マグネット，交流超電導技術に関する研 究に従事。低温工学協会, 応用物理学会会員。

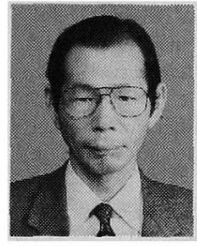

梅 田 政 一 (正員)

昭和 19 年 11 月 15 日生。 40 年 4 月電 気試験所（現，電子技術総合研究所）入 所。 42 年 3 月東京電機大学 2 部工学部 電子工学科卒業。主として, 化合物超電 導体ならびに超電導マグネットの研究, 開発に従事。応用 物理学会, 低温工学協会会員。

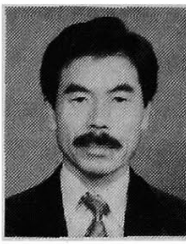

我 妻 洸 (正員)

昭和 42 年 3 月早稲田大学理工学部電 気工学科卒業。同年 4 月電気試験所 (現, 電子技術総合研究所) 入所。以来, 超電導応用および低温工学の研究に従 事。現在, エネルギー部超電導応用研究室主任研究官。工 学博士。低温工学協会会員。

\& 